\title{
Discovering "os ianques do sul": towards an entangled Luso-Hispanic history of Latin America ${ }^{1}$
}

\author{
Descobrindo "os ianques do sul": em direção a uma \\ entrelaçada história luso-hispânica da América Latina
}

ORI PREUSS*

Rev. Bras. Polít. Int. 56 (2): 157-176 [2013]

In July 1906, two gentlemen, one a prolific essayist, former leader of Brazil's abolitionist movement, and its current ambassador to the United States, the second, an internationally renowned Nicaraguan poet, journalist, and occasional diplomat, crossed the Atlantic on the same boat with other Spanish American delegates, to participate in the third Pan-American Conference in Rio de Janeiro. For Joaquim Nabuco the conference was to be a crucial step toward realizing his vision of a spiritual unification of the continent under the tutelage of the United States; a project which had earned him the reputation of an ardent Monroeist, "more Yankee than the Yankees themselves," in the words of a friend. ${ }^{2}$ Rubén Darío, in contrast, had recently published his anti-Yankee manifesto "A Roosevelt," condemning, in the name of "our America," that "wealthy country" to the North "joining the cult of Mammon to the cult of Hercules; while Liberty, lighting the path to easy conquest, raises her torch in New York."

Several years later, during a second visit to Brazil, Darío would recount some of the details of that maritime encounter in an extended lecture about Nabuco. ${ }^{4}$ What exactly was said between the two on board, en route to the 1906 conference, remains unknown. What we do know, is that once on Brazilian soil, Darío would write his "Salutación al águila," summoning the magic eagle of the North to

\footnotetext{
1 Previous versions were presented at the "Writing Across the Americas: Policies, Politics, Poetics," Colloquium at Tel Aviv University, May 2012, and at the "Erasing or Erecting Boundaries?" symposium about Brazilian and Latin American Studies, at the University of Columbia, November 2012. I would like to thank the participants of both conferences, and especially Barbara Weinstein, for their helpful comments.

* Ori Preuss is a Professor at the History Department of Tel Aviv University, Tel Aviv, Israel (oripreuss@gmail.com). 2 José Veríssimo to Oliveira Lima, Rio de Janeiro, Aug. 12, 1906, Oliveira Lima Library, Washington DC, Oliveira Lima Family Papers.

3 Darío, Rubén, and Lysander Kemp. Selected Poems of Rubén Dario (Austin: University of Texas Press, 1965), p. 69.

4 Fred P. Ellison, "La conferencia de Rubén Darío sobre Joaquim Nabuco: introducción y texto," Revista Iberoamericana 27:52 (2009), p. 343.
} 
spread his great continental shade over the South. The poem seemed to represent a change of faith. One month later, though, Darío would apologetically confess, in another poem, how he had "Pan-Americanized [himself] in the land of diamonds and tropical bliss with a vague fear and with very little trust." ${ }^{5}$

Darío, unlike Nabuco, has been widely considered one of the main protagonists of turn-of-the-century Latin Americanism, generally characterized as a more or less idealistic intellectual trend, and associated with "a group of writers and thinkers generally known by the vague name of modernistas." Reacting in large part to US expansionism, and acting independently from the centers of political power, these intellectuals famously pitted an idealistic, spiritual Latin America against a utilitarian, materialistic Anglo-Saxon America. The essay Ariel (1900), by the Uruguayan José Enrique Rodó, is widely considered the quintessential text of the movement, and the antagonistic, binary identification it promoted has been often termed accordingly Arielismo. As Cuban literary critic Roberto Fernández Retamar has written with regard to the Spanish-Cuban-American war of 1898, "it is ninety-eight, the presence of North American imperialism in Latin America, already foretold by Martí, which informs the later work of someone like Darío or Rodó." ${ }^{\circ}$ Other scholars have highlighted the elitist and/or racist nature of Latin Americanism, depicting it as a conservative elitist response to domestic threats from below. According to this line of interpretation the very "idea of Latin America” was "a political project of Creole-Mestizo elites [which] lifted up the population of European descent and erased the Indian and the Afro populations [...] Latin America as a political and ethical project was the ethos of internal colonialism."7

In this sense, the historiography of the concept of "Latin America" is emblematic of wider trends in Latin American studies. Strongly informed by dependency or postcolonial theory, and highly state-centered, the scholarship concerning national and supranational identification in nineteenth-century Latin America has revolved around asymmetrical relations of power-be those relations of domination, confrontation, or negotiation - both between center and periphery and within each country of the periphery. Whether writing with a top-down

5 "Epistola a la Sra. de Leopoldo Lugones," cited in Alberto Acereda, and Rigoberto Guevara, Modernism, Rubén Dario, and the Poetics of Despair (Lanham, MD: University Press of America, 2004), p. 279. About this poem and Dario's ties to Brazil, see Juan Manuel Fernández, "Rubén Darío: una obnubilação brasílica," Caracol 3 (2012), pp. 103-133.

6 Roberto Fernández Retamar, "Caliban: Notes towards a Discussion of Culture in Our America," The Massachusetts Review 15:1/2 (1974), pp. 17-18. This is a much generalized overview of a more nuanced scholarship produced almost solely by literary critics. Important contributions by historians are Oscar Terán, "El primer antiimperialismo latinoamericano," En busca de la ideología argentina (Buenos Aires: Catálogos, 1986), pp. 85-97: Mónica Quijada, "Latinos y anglosajones: el 98 en el fin de siglo sudamericano," Hispania 57:196, (1997), pp. 589-609; Nicola Miller, In the Shadow of the State: Intellectuals and the Quest for National Identity in Twentieth-Century Spanish America (London: Verso, 1999), chapter 5.

7 Walter Mignolo, The Idea of Latin America (Malden, MA: Blackwell, 2005), pp. 59, 65. 
or a bottom-up approach, implicitly or explicitly, historians and literary critics have directed their attention to two main axes of interaction, the first connecting Latin America's upper classes with Europe and the United States, and the second connecting these predominantly white, upper classes with the "colored" masses of their respective countries.

This article argues for the importance of a third axis of interaction, namely the trans-Latin American axis, or what might also be called a histoire croisée, an entangled history, of the region, to be distinguished from comparative history. "Within a histoire croisée perspective, the transnational [...] is apprehended as a level that exists in interaction with the others, producing its own logics with feedback effects upon other space-structuring logics." 8 According to this principle, and as already hinted by the multidirectional intersecting political-poetic itineraries of Nabuco and Darío, a truly integrative intellectual history of "Latin America," with or without quotes, must pay attention to transnational intercrossings inside the region. This I will demonstrate by reconstructing the largely forgotten role of key Brazilian intellectuals in the Latin versus Anglo-Saxon debates that developed around 1898, and by emphasizing the embeddedness of their thinking in the growing circulation of men and ideas across national borders within the South, principally in the River Plate region. ${ }^{9}$ Here, the overall Latin American trend toward connectedness was most notable. Shifting attention away from the usual Spanish American suspects and their repeatedly cited essays such as Rodó's Ariel, this change of focus does not only challenge the common depiction of Latin Americanism as a purely Spanish American phenomenon and of the United States as its major catalyst, but also allows a more nuanced understanding of the movement's nature. In the case of Brazil, as we shall see, it was intricately tied at once to the interpretation and the practice of international relations, and it had

8 Michael Werner, and Bénédicte Zimmermann, "Beyond Comparison: Histoire Croisée and the Challenge of Reflexivity," History and Theory 45:1 (2006), pp. 30-50.

9 There are some pioneering works that focus on the growing transnational literary exchange in late nineteenth century Spanish America. See, among others, Susana Zanetti, "Modernidad y religación: una perspectiva continental (1880-1916)," in Ana Pizarro, ed., América Latina, palabra, literatura e cultura, vol. 2 (Campinas: Editora da Unicamp, 1994), pp. 489-534; Angel Rama, "La modernización literaria latinoamericana," in La crítica de la cultura en América Latina (Barcelona: Biblioteca Ayacucho, 1985), pp. 82-96. Common to all is the explicit exclusion of Brazil under the claim that Brazilians did not take part in this historical process. Leslie Bethell, "Brazil and 'Latin America', Journal of Latin American Studies, 42:3 (Aug. 2010), pp. 457-485, a rare historical overview of Brazil's diplomatic and intellectual relationships with Spanish America, generally endorses this claim, although the author concedes (p. 470) "a somewhat greater degree of interaction" between Brazilian and Spanish American intellectuals, and a greater Brazilian awareness of the economic and political progress achieved by some neighboring countries during the First Republic. An important case in point, which has recently received attention, is the Revista Americana launched under the auspices of the Brazilian Foreign Office in 1909. This was one out of various instruments of cultural diplomacy used for intellectual exchange and achieving rapprochement with Spanish America during the tenure of dominant foreign minister Baron of Rio Branco (1902-1912), a period largely beyond the scope of this article. See Alvaro Fernández-Bravo, "Utopías americanistas: la posición de la Revista Americana en Brasil (1909-1919)," In Paula Alonso, ed., Construcciones impresas: Panfletos, diarios y revistas en la formación de los estados nacionales en América Latina, 1820-1920 (Buenos Aires: Fondo de Cultura Económica, 2004), pp. 321-338. 
both idealist and realist variants, ${ }^{10}$ all this due to the fact that Brazilians came to identify themselves not with one but with two Latin Americas.

\section{The American illusion}

Negative images of the United States as an expansionist country and/or of its Anglo-Saxon citizens as a bestial avaricious lot had existed in Brazil from at least mid-century. ${ }^{11}$ The following quote from the editors of $O$ Novo Mundo, a Portuguese-language journal of republican inclination, basically favorable to the United States, which was published in New York and designed for Brazilian readership in Brazil, is telling: "Nothing gives us more pleasure, for example, than to attend to the presumptuous vanity with which some of our 'statesmen' and carpet-baggers speak about this disgusting mass of Americans who spend their life kneeling before the god of the dollar and reciting their kyrie: time is money. We do not strive, and never have, to Americanize Brazil." 12 This said vanity clearly characterized the young Joaquim Nabuco, who, in 1877, while serving as attaché to the Brazilian legation in the United States, noted in his diary that "man here is a money-making machine, humanity's clear goal is to get rich, the dollar is the god of this plutocracy of forty million men."13 In the same year, also in New York, poet Joaquim de Sousa Andrade, or Sousândrade, published his poem O inferno de Wall Street, an attack on US materialism mentioned by literary critic Jean Franco as a precursor of Arielism. ${ }^{14}$

Yet it was not until the military coup of November 15, which installed the first republic in 1889, that such views of the Northern Other started to feed into the construction of a supra-national Latin American Self. Why? Here the trans-Latin American context is crucial. Since the early days of Latin American independence the institution of the monarchy loomed large in the self-image of Brazil's political and intellectual elite. The stability and unity achieved by the regime created a feeling of superiority vis-à-vis Spanish America, which had disintegrated into numerous turbulent republics, ruled by caudillos. From then on, the imperial elite saw and presented Brazil as a monarchical island of civilization in a sea of caudillo barbarism. This long-standing isolationist mental structure, which had come under

10 For an innovative discussion of these aspects in the cases of other countries, see Liliana Obregón, "Regionalism Constructed: A Short History of 'Latin American International Law'," European Society of International Law (ESIL) Conference Paper Series No. 5, 2012; Juan Pablo Scarfi, "Entre la nostalgia del Virreinato del Río de la Plata y la unión latinoamericana: La emergencia de un imaginario moderno antiestadounidense en la Argentina (1880-1913)," forthcoming in Revista Complutense de Historia de América.

11 Natalia Bas, "Brazilian Images of the United States, 1861-1898: A Working Version of Modernity?” PhD diss., (University College London), 2011, pp. 320-325.

12 “Um contraste," O Novo Mundo, May 23, 1875, p. 190.

13 Joaquim Nabuco, Diários (Rio de Janeiro/Recife: Bem-Te-Vi/Fundação Joaquim Nabuco, Editora Massangana, 2005), entry for March 10, 1877, vol. 1, p. 124.

14 Jean Franco, The Modern Culture of Latin America: Society and Artist (London: Praeger, 1967), pp. 49-50. 
attack of Brazilian republicans and of other liberal reformers since the early 1870 s, collapsed almost entirely with the fall of the monarchy. ${ }^{15}$

The 1889 revolution opened a dual battle, strongly tied to politics, between two opposing interpretations of the nation. The first one, promoted by the new regime, tended to downplay the uniqueness of Brazil in America, erasing its Portuguese legacy. The Brazilian identity was to be forged as part of a broader American identity based on common values and political forms that unified the New World and distinguished it from the Old. This orientation generated a renewed appreciation of Brazil's unique historical path and Luso-Catholic character in the rival Monarchist camp. ${ }^{16}$ Yet even monarchists now recognized, albeit reluctantly, that Brazil was no longer an island.

It was in 1893 that the main spokesmen of the monarchist camp, Eduardo Prado, published his anti-Yankee treatise, $A$ ilusão americana, a text that was widely discussed during the period. Prado, a legitimate son of São Paulo's coffee aristocracy, who in the early 1880 s went on a grand tour to Europe with stops in Uruguay, Argentina, Chile, and the United States, focused his attack on the republic's North American orientation. Significantly, though, the frame of the discussion was continental rather than bilateral. Prado lambasted the unhealthy influence-political, economic and moral—of a selfish expansionist United States, not only over Brazil, but over Spanish America as well.

A ilusão americana started with a strong refutation of the idea of affinity both between Brazil and the "Anglo-Saxon republic" and between Brazil and the "Iberian countries of America." Yet the total negation of any similarity or friendship with the latter stood in tension with a repeated usage of the concept and the term "América Latina." Completely missing from Prado's travel accounts and other writings from before 1889 it was repeatedly employed here to designate a group of nations that were essentially different from the United States in terms of history, culture and "race." Prado argued, for example, that by installing the Republic, Brazilians repeated the same grave error which the Spanish Americans had committed right after gaining their independence, that is, the error of "implanting in Latin America the [political] institutions of a foreign race." Moreover, in the last section of the book, dedicated to the discussion of moral issues, Prado set "the respect for human life and liberty" as the true measure of a given people's level of civilization. According to this criterion, he maintained, the United States was inferior to Brazil, since the spirit of the first was "violent," whereas "the Latin spirit" of Iberian origins of the latter was "juridical [...], maintaining a certain

15 Ori Preuss, "Brazil into Latin America: The Demise of Slavery and Monarchy as Transnational Events," Luso-Brazilian Review 49:1 (June 2012), pp. 96-103.

16 On political debates about national identity during the early republic, see José Murilo de Carvalho, $A$ formação das almas (São Paulo: Companhia das Letras, 1993); Lúcia Lippi Oliveira, A questão nacional na Primeira República (São Paulo: Brasiliense, 1990); Preuss, "Brazil into Latin America." 
respect for human life and liberty." 17 Written five years before the Spanish-CubanAmerican War in the Brazilian context of transition from Empire to Republic, this highly politicized diatribe already featured not only the racialization and cultural essentialism that would typify the post-1898 Spanish American discourse about the United States, but also what Mónica Quijada has called "the inversion of dichotomies." That is, the interpretation of Latin America as morally superior to Anglo-Saxon America instead of biologically inferior. ${ }^{18}$

It is for these features that the $A$ ilusão americana has been rightly mentionedanachronistically, let us note-in the same breath as Rodó's Ariel, published seven years later, in $1900 .{ }^{19}$ Yet $A$ ilusão americana was a Latin American text not only by virtue of its themes and geo-cultural scope but also of its explicit reliance on Spanish American sources and bibliography in the building of the arguments. Prado cited, among others, Ensayo sobre las revoluciones politicas y la condición social de las repúblicas hispano-americanas (1861), by Colombian liberal José María Samper; De la navegación del Amazonas: respuesta à una memoria del M. Maury, by Argentine historian Pedro de Angelis (1857); and Le droit international théorique et pratique (1868), by Argentine jurist Carlos Calvo. These inter-textual bridges were another indication that Brazil was no longer an island, neither politically, nor intellectually.

Soon, similar discursive patterns appeared among disillusioned republicans as well, in the person of the Republic's first minister of finance and the major author of its constitution (largely modeled on the US Constitution), Rui Barbosa, who became a leading critic of the regime during the rule of the Iron Marshall Floriano Peixoto (1891-1894). Persecuted by the government for alleged involvement in the 1893 Naval Revolt, senator Barbosa fled to Buenos Aires, where he stayed for several months before continuing to Europe. Attacking the Republic's rapprochement with the United States from exile in 1894-1895, he portrayed himself both in private and in public as an admirer of the United States for its spirit of liberty and material progress, only to ridicule the "monomania of adulation for a country that so openly scorns us and whose policy toward the other republics of the hemisphere is so scandalously oppressive." ${ }^{20}$ In a newspaper article published in Portugal he coined a neologism warning against absorption in "panyankismo," and called for a trustful relationship with Europe which "elevated America from Barbarism" and to which it owed its population, language, religion, culture and prosperity: past, present and future. On this point Rui referred his readers to the ideas of Argentina's leading jurist Juan Bautista Alberdi (1810-1884), whose writings he

17 Eduardo Prado, A ilusão americana (eBookBrasil, 2002 [1893]), pp. 57-58, 177. A second edition appeared in 1895 , and a third one in 1902.

18 Quijada, "Latinos y anglosajones," pp. 599-604.

19 José Murilo de Carvalho, "Brazil 1870-1914: The Force of Tradition," Journal of Latin American Studies 24 (1992), pp. 158-159.

20 Rui Barbosa to Carlos Aguiar, London, March 12, 1895, excerpted in Luís Viana Filho, A vida de Rui Barbosa, 8th ed. revised (Rio de Janeiro: Livraria J. Olympio Editora, 1977), p. 238. 
knew very well. ${ }^{21}$ Alberdi was cited favorably again in another article, written in London and published in Rio's Jornal do Comércio in 1895, this time alongside Los Estados Unidos y la America del Sur: los yankees pintados por si mismos (1893), by Argentina’s former minister in Washington, Vicente G. Quesada. Importantly, from the perspective of trans-Latin American intellectual crossings, Rui saw fit to mention that he had read this cornerstone of Argentine anti-North Americanism while in his first place of exile, Buenos Aires. ${ }^{22}$

Later in 1895, now back in Rio, he composed a short declaration against the Brazilian Senate's endorsement of President Grover Cleveland's message to Congress, which had asserted the claim of the United States to intervene in the dispute between Venezuela and England. Rui's statement censured this recent application of the Monroe Doctrine as an expression of US hegemony over "the two Americas," and repeated his call for a trustful relationship with Europe, "to which we owe our civilization," reasoning that "the ambitions that today threaten us are located in this continent rather than in the Old." ${ }^{23}$ Interestingly, the text was destined for publication in the New York Herald and La Prensa of Buenos Aires. Indeed, as we shall see, the urban press in Argentina and Brazil had been a major vehicle for the circulation of information and ideas in both directions, thus creating a shared discursive space into which Rui consciously inserted himself not for the first time. In sum, like Eduardo Prado, he also drew on Spanish American sources, framing the question of US imperialism in terms of a civilizational confrontation between North and South rather than as a narrowly national strategic matter.

\section{The sick continent}

The emergence of a new anti-Yankee, Latin Americanist discourse in Brazil should be understood in relationship to the appearance of another discourseproduced by the very same writers — during the early republic, that is, the diagnostic discourse concerning governability. The fall of the monarchy meant a break not only at the symbolic level. While the newly established republican regime stressed once and again the nonviolent character of the revolution, and adhered to American values of peace and liberty, events on the ground were more reminiscent of Spanish America's age of caudillos, as the regime's critics were quick to point out. Radically new circumstances of a military government, political instability, fratricidal violence, and repression, unknown in Brazil for decades, were all seen and

21 "O Brasil e os Estados Unidos," Correio da Manhã (Lisbon), May 22, 1894. Rui's personal library has all eight volumes of the 1886-1887 edition of Alberdi's Complete Works. The first references to Alberdi's writings in Rui's Obras Completas date from 1889.

22 "As bases da fé," republished in Cartas de Inglaterra (Rio de Janeiro: Leuzinger, 1896), pp. 39-41. About the centrality of Quesada and his text, see Scarfi, op. cit.

23 Arquivo da Casa de Rui Barbosa (henceforth, ACRB), RB-RBPI 23. 00-00-1895. I was not able to verify whether the declaration was actually published in the mentioned newspapers as planned. 
described as signs of Hispano-Americanization, giving rise to outright expressions of belonging, albeit unwillingly, to an entity called "Latin America." 24

In a manifesto which constituted his first elaborate comment on the change of regime, liberal-monarchist Joaquim Nabuco repeatedly evoked the tumultuous political life of Spanish America, where, "despite the growing stability among all these peoples," the rule was still "Vae Victis, [...] physical or moral annihilation of the adversary." It was as if the Brazilian elite's deep-rooted image of Spanish America as anarchic and tyrannical by nature, which had been losing ground since circa 1870 , came back to life. Yet now, after the monarchy had fallen, political instability and violence were no longer viewed as a uniquely Spanish American fate, but rather as a common destiny of the "Latin" nations of the continent: "How could we have nurtured the belief," summed Nabuco, "that we as a republic would not go through the same via dolorosa as that along which Latin America is sluggishly dragging herself." 25

At about the same time, his fellow monarchist Eduardo Prado published a series of articles, which soon appeared in book form under the title Fastos da dictadura militar no Brasil. Prado's line of argument in this sarcastic unrelenting attack on the newly established Republic was very similar to Nabuco's: the new regime is militaristic; military intervention in politics, or caudillismo, is a Spanish American phenomenon; hence, Brazil has become like its neighbors and an integral part of Latin America. Or worst, it has become like some of them had used to be: "The Brazilian military tyranny of today can be regarded as that invincible period of barbarity that is already past in Chile, possibly just ended in Argentina, and in which all other countries in Latin America still live, to one degree or another." 26

By 1893 , with the fast-increasing militarization and brutalization of Brazil's political life, the notion of Hispano-Americanization also appeared in the writings of republican leaders, again in the person of Rui Barbosa. During his period of exile in Buenos Aires he published a series of programmatic articles destined for Brazilian readership in the city's prestigious newspapers La Prensa and La Nación, an act which he defended by placing it in an explicitly-defined Latin American context. To take advantage of the freedom of speech in Argentina in order to denounce the political repression in Brazil, was to take advantage of "a right that is as old as the history of the military tyrannies in America, a right invoked, throughout the ages,

24 Scholars (see e.g. Bethell, "Brazil and 'Latin America," p. 470) have tended to conflate negative views of Spanish America with lack of identification. Yet, as Tzvetan Todorov has noted, value judgments of the Other operate on a distinct level from approximation/distancing from the Other-they are not mutually dependent; see The Conquest of America: The Question of the Other, trans. by Richard Howard (New York: Harper Perennial, 1992), pp. 185-186.

25 Joaquim Nabuco, Resposta às mensagens do Recife e Nazareth, 2nd. ed. (Rio de Janeiro: Leuzinger, 1890), pp. 8-15. The same notions were repeated in his Porque continuo a ser monarchista (London: Abraham Kingdon \& Newnham, 1890).

26 Eduardo Prado, Fastos da dictadura militar no Brasil 3rd. Ed. (São Paulo: Escola Typografica Salesiana, 1902 [1890]), p. 48. 
by all those shipwrecked in the stormy seas of caudillism in this continent." The main advocate of civil liberties in Brazil further identified himself with prominent leaders of Argentine liberalism who had campaigned against Juan Manuel de Rosas' tyranny (1829-1852) from exile. In particular, he singled out the writings of Alberdi, held "dear by all the friends of free institutions in Latin America." ${ }^{27}$ In the same way as Prado and Nabuco, Rui evoked a vision of Spanish America and Brazil as part of one and the same space of struggle between the forces of authoritarianism and/or disorder on the one hand, and of (conservative) liberalism and order on the other.

This new-born vision of Brazil as an integral part of Latin America based on the recent experience of "caudillism" received its fullest expression in two lengthy essays published in 1895, Duas glórias da humanidade by Rui Barbosa, and Balmaceda by Joaquim Nabuco. ${ }^{28}$ Both texts criticized the authoritarian rule of Floriano Peixoto in Brazil through a discussion of Spanish American heads of state: Paraguay's José Gaspar Francia (1814-1840) and Argentina's Rosas in the first, and Chile's José Manuel Balmaceda (1886-1891) in the second. The dictatorships of these early nineteenth-century caudillos and the 1891 civil war in Chile stood for a general diagnosis of "Latin America" as suffering from chronic political disorder and traditional despotism. Rui concluded his essay with the verdict that "Francia and Rosas were nothing more than two incarnations, similar to others, of a renascent, possibly organic, general social condition in Latin America." Nabuco even prescribed a remedy. This should be sought, he wrote in the first-person plural, "inside each and every one of our countries [...] in all of them there are men of cultural stature [...] who can form the Liberal League of the Continent. The cause is, in fact, a shared one." ${ }^{29}$

As in the case of the anti-US texts by Eduardo Prado and Rui Barbosa discussed above, these two essays were also embedded in Luso-Hispanic American encounters and exchanges. Rui's discussion of Rosas drew heavily on Argentine historian Mariano Pelliza's La dictadura de Rosas (1894), as well as other writings by Alberdi and Domingo Faustino Sarmiento, while Nabuco's discussion of Balmaceda was defined by the author himself as "a study of the book" Balmaceda: su gobierno y la revolución de 1891 (1894), by Chilean statesman-writer Julio Bañados Espinosa. Moreover, both authors evoked their visits to Argentina as a source of knowledge about their subject-matters. Nabuco recalled meeting Chilean exiles at the home of "a Chilean friend" in Buenos Aires in 1891, and reading articles by another Chilean writer, Francisco Valdés Vergara, about the civil war that had

27 "Quarta carta a La Nación," Nov. 13, 1893, in Obras completas de Rui Barbosa (Rio de Janeiro: Ministério da Educação e Cultura, 1942-), vol. XX, t. I, pp. 354-359.

28 Both texts first appeared as serialized articles in Jornal do Commercio and then in book form: Joaquim Nabuco, Balmaceda (Rio de Janeiro: Leuzinger, 1895); Rui Barbosa, "Duas glórias da humanidade," in Cartas de Inglaterra, p. 333.

29 Nabuco, Balmaceda, p. 215. 
been going on across the Andes in the city's newspaper La Prensa. Rui, on his part, recalled drawings of Rosas he had seen in the Argentine capital, integrating his impressions of them into Pelliza's written portrait of the caudillo.

\section{A Brazilian 1898}

The relationship between the perception of Brazil as an organ of a sick body called "Latin America" and attitudes toward the United States-only latent in texts from the mid-1890s - became manifest under the impact of the SpanishCuban-American war of 1898. "I am among those who think," wrote Joaquim Nabuco to a friend in early 1899 ,

that our national decay has begun; that we are entering the [North] American orbit, like Cuba and the Philippines, Mexico and Nicaragua; that our evolution will follow the same path as the other satellites of Washington, and that the only way we can achieve some dignity and lead an independent life-intellectually, that is - is to produce several brilliant spirits who will elevate our literature beyond the contingencies of political and material absorption or elimination. ${ }^{30}$

If, previously, Nabuco posited literary creation as an answer to the malady of political disorder — or to the "tiger within," to use José Martîs imagery in "Nuestra América" - then now, after 1898, it becomes the answer to the tiger outside as well. The twin, mutually feeding existential threats of autochthonous caudillismo on one hand, and foreign imperialism on the other, elicit a unified idealistic response. The former abolitionist leader, a champion of state reform and social transformation, abandons all worldly projects and suggests instead a spiritual regeneration, with what may be called, again anachronistically, Arielista overtones.

Clear line can be traced from Nabuco's instant reaction to 1898 , to the cultural-political project he would pursue as the first Brazilian ambassador to the United States from 1905 until his death in 1910. His view of the Brazilian predicament as forming part of a wider "Latin American question" lay at the basis of his Monroeism. The creation of the Washington embassy was in his words an "act of audacity and inspiration that opens new and extended horizons for our country and for all of Latin America." 31 Close relations with the United States and an unconditional acceptance of the Monroe Doctrine were the only possible guarantees against foreign aggression, he now had come to believe. He combined this policy with a complementary spiritual project of "unifying the civilization of the whole American continent," as he defined it in his opening speech as president

30 Joaquim Nabuco to Carlos Magalhães de Azeredo, Rio de Janeiro, Feb. 14, 1899, in Joaquim Nabuco, Cartas a amigos, 2 vols. (São Paulo: Instituto Progresso Editorial, 1949), vol. 2, p. 5.

31 Joaquim Nabuco to Graça Aranha, Rome, Feb. 2, 1905, Cartas a amigos, vol. 2, p. 208; my italics. 
of the Third Pan-American Conference. ${ }^{32}$ This was the ideological translation of his pessimistic concept of Latin America. Yet the very same endeavor to construct an all-American civilization, to bridge the gaps, ultimately drew on, and perpetuated, the concept of two essentially distinct Americas, "Anglo-Saxon" and "Latin," profoundly indifferent, if not hostile, to each other. ${ }^{33}$

But Nabuco was not the only prominent Brazilian man-of-state-and-letters to point out the far-reaching significance of 1898 , nor was his idealism the sole response to it around. The implications of the war were also discussed in the journalistic writings of Rui Barbosa, who by then returned from his exile to become again a senator and a newspaper editor. In 1899, he penned a series of articles about the danger looming in the North, describing the advent of the United States into the group of what he termed the "hunting nations," as "the most important novelty of this era." ${ }^{34}$ Drawing on works by Argentine authors Carlos Calvo, Bartolomé Mitre, and, again, principally Alberdi, and alluding to Prado's A ilusão americana, Rui called upon Brazilians to abandon any North American illusions. There would be no exceptions to the rule, he warned: "Together with Indians and half-breeds, so each and every descendant of Spain and Portugal beneath this sky and, together with the most infamous and weakest republics of this continent, also the best and the strongest, such as Mexico, Argentina, and Chile, will be thrown into the cauldron that awaits the arrival of the Pantagruelian invaders." ${ }^{35}$ Apparently, in Rui's eyes, there was not one, but at least two Latin Americas, notwithstanding their common fate.

The division of Latin America into two discrete categories - the infamous and weak, and the best and strong-reveals an ambivalent attitude toward the dominant social Darwinist logic of the day, an attitude deriving from Rui's double location in a country he himself perceives as at once powerful and helpless. He condemns the "survival of the fittest" mandate in international relations but at the same time adopts it, applying terminology and moral standards from the NorthSouth context to South-South relationships. Here is one type of reaction to the European and North American tendency to lump the countries of Latin America together as potential prey. However, these outside threats could simultaneously produce, as Rui's case exemplifies, an opposite type of response as well.

32 Third international American Conference, 1906: Minutes, Resolutions, Documents (Rio de Janeiro: Imprensa Nacional, 1907), p. 44.

33 Concept best expressed in his The Approach of the Two Americas: Convocation Address before the University of Chicago, August 28, 1908.

34 Rui Barbosa, "A nova potência militar," April 9, 1899, Obras Completas, vol. XXVI, t. IV, 249-262. Other articles in the series included "A higiene e a expansāo americana," April 11, 1899, "Chinas americanas," April 18, 1899, "O futuro dos Estados Unidos," April 18, 1899, Obras Completas, vol. XXVI, t. IV, pp. 269-274, 315-320, 321-326; "O continente enfêrmo," May 3, 1899, "O deleixo latino-americano," May 4, 1899, "Vã confiança - A ilusão americana," May 29, 1899, "Vã confiança - A doutrina de Monroe: sua origem," May 30, 1899; "A história repete-se," June 9, 1899, Ibid., vol. XXVI, t. V, pp. 15-18, 19-22, 151-154, 155-162, 217-226.

35 Barbosa, "Chinas americanas," p. 317. 
Thus, the notion of two Latin Americas which had been put forward in the first articles of the series gave way in the fifth and sixth to a concept of "Latin America" as a unified whole. Both texts relied heavily on a recently published pamphlet titled El continente enfermo (1899) by the Venezuelan César Zumeta. Rui borrowed this diagnostic caption for one of his own articles, endorsing fully the latter's observations regarding the hostile intentions of the United States and the unpreparedness of the Latin American countries_ "the threatened peoples," was one of Zumeta's cited monikers-in the face of the danger. ${ }^{36}$ The reliance on a Spanish American text is all the more intriguing in view of Rui's own opening remark that Zumeta's pamphlet plants the same questions that he himself had already presented several times to the readers of $A$ Imprensa. One may conclude, then, that the only function of the dialogue with the Venezuelan intellectual had been to emphasize the shared nature of the threat, the common fate.

This emphasis reached its apex in the second of Rui's two Luso-HispanoAmerican duets with Zumeta, in which he had moved to refer to Latin America in the first-person plural. Moreover, he listed some typical traits of the Latin "race"- "vanity, improvidence, and imagination"- that, together with the glorious memories of the independence period, bring Latin Americans to falsely believe that they can perpetuate their freedom, turning a blind eye to the change of circumstances around them. ${ }^{37}$ The construction of "Latin America" on the twofold basis of fixed ethnic attributes and historical specificities is reminiscent of Nabuco, and so is the somber view of the region's future. However, although the two Brazilians share similar preoccupations, they differ on cures. A much more realistic Rui, for whom "imagination" is a dangerous trait, does not seek salvation in the spiritual realm, proposing instead, as we shall see ahead, more mundane measures.

\section{Strugforlifista Latin Americanism}

Rui Barbosa's diagnosis of the post-1898 international situation was quite similar to Nabuco's. Yet not so the cure. This became apparent in the discussion that accompanied the exchange of presidential visits between Brazil and Argentina in 1899 and 1900, events celebrated with high solemnity and extensive press coverage in the public spaces of Rio de Janeiro and Buenos Aires. Several days before the arrival of President Julio Roca in Rio in August 1899, Rui applauded in his newspaper the rapprochement between two "peoples of the same race, the same religion, and nearly the same language [...] that are close to each other in terms of geographical continuity, history, and a common American interest." ${ }^{38}$ These words

36 Barbosa, "O continente enfêrmo," p. 15.

37 Barbosa, "O deleixo latino-americano," p. 19.

38 "Não desafinemos," A Imprensa, Aug. 2, 1899, in Obras Completas, vol. XXVI, t. VI, p. 194. 
were important enough to win the gratitude of the Argentine minister to Brazil who, in a pathos-filled letter to Rui, accorded the bilateral encounter continental significance, defining its ultimate goal as the "aggrandizement of Latin America."

During the two visits, Rui, like other official and non-official voices on both sides, raised the notion of active cooperation between what he called "the three grand nations of South America," couching it again in a mixed discourse of geo-strategy, moral values, history, and ethnicity. A process of approximation between Argentina, Chile, and Brazil (henceforth ABC) had started thanks to a growing shared awareness of a common interest: "to vigorously safeguard the Latin contingent in America." Thus claimed Rui on the day that the Argentine dreadnought San Martin, carrying Roca, entered the Guanabara Bay accompanied by the cruiser Buenos Aires and the torpedo boat Patria. Argentina's president, who before coming to the Brazilian capital met with his Chilean counterpart on board a warship down South at the straits of Magellan, won Rui's approval for laying the basis for "southern peace and Latin security in the continent of Columbus." 40

This idea of joining forces was pronounced even more bluntly the day afterward, in a detailed comment on a recent interview with the Brazilian minister to the United States, and former minister to Argentina, Joaquim Francisco de Assis Brasil, that had been published in the New York press. Here Rui supported Assis Brasil's allusions in the interview to a South American alliance in the face of North American expansionism, but criticized him for being too open. ${ }^{41}$ Assis Brasil's statements indeed deviated from the official Brazilian stand on this matter, yet Rui's vision of "Latin" cooperation amidst US and/or European imperialism was not unique to him. Assis Brasil himself proposed several months later, this time confidentially, an economic-security alliance between Brazil, Argentina, Chile, and Uruguay, countries which had all the reasons to cooperate as they shared "the same race, the same religion, and almost the same language." 42

The possibility of an ABC league would be on the agenda of foreign policymakers in the three countries in following years without much tangible results. ${ }^{43}$ From our perspective, however, what matters is the birth of the idea itself and the spiritual climate from which it emerged. The tumult of the early republic was now over. The Brazilian elites, like their counterparts across the River Plate, had fashioned a stable oligarchic ruling arrangement. The notion of an ABC alliance embodied their shared concerns, interests and worldviews. It reflected the growing stakes of Brazil's and Argentina's governing classes in

39 Argentine Minister Manuel Gorostiaga, Petrópolis, to Rui Barbosa, Aug. 2, 1899, ACRB, CR 1589.1/1.

40 "Um dia histórico," A Imprensa, Aug. 8, 1899, Obras Completas, vol. XXVI, t. VI, pp. 197-200; my italics.

41 Rui Barbosa, "Frutas do Tempo," A Imprensa, Aug. 9, 1899, in ibid., pp. 201-206.

42 Brazilian Minister, Washington, to Foreign Minister, Jan. 31, 1900, in Assis Brasil um diplomata da República (Rio de Janeiro: CHDD/FUNAG, 2006), vol. 1, p. 253.

43 Joseph Smith, Unequal Giants: Diplomatic Relations between the United States and Brazil, 1889-1930 (Pittsburgh: University of Pittsburgh Press, 1991), pp. 39-40. 
securing peace both domestically and regionally. Aims were not only to prevent conflicts within and along their national boundaries, but to guarantee stable and responsible government among the smaller republics of South America as well. The local powers were to assume the role of regional policeman similar to that of the United States in the Caribbean. These objectives were linked, in turn, to intensifying anxieties over European and/or North American imperialism, mixed with growing self-confidence and mutual respect. An expression of this mental state, the triple presidential encounters were a transnational celebration of South American virility, military might, and economic prosperity; a spectacle of Pazy Administración, Ordem e Progresso, to employ the corresponding mottos of the Argentine and the Brazilian governments. ${ }^{44}$

Yet it is also important to note what was missing from that show: namely, idealism à la Nabuco or Rodó. If 1898 encouraged the emergence of an antimaterialist intellectual movement in Latin America, it was hardly evident in the discourse of Brazilian-Argentine rapprochement. If Arielismo was rooted, as Jean Franco has argued, in the powerlessness of Latin American intellectuals "to act or to affect the destiny of their continent except in the realm of ideas," 45 then the exchange of visits and the notion of an $\mathrm{ABC}$ alliance revealed a very different, realist, or strugforlifista - to borrow a term coined by Brazilian intellectual José Veríssimo in reference to the United States ${ }^{46}$ —response to shared Luso-HispanicAmerican nightmares. Still, this line of thinking and action must not be seen only in terms of sheer power and pragmatism, as it was intimately entwined with the already mentioned dual vision of "Latin America" as at once weak and powerful. Thus, when Brazil's influential foreign minister Baron of Rio Branco (1902-1912) promoted a cooperation agreement with Chile and Argentina along the ideas of Rui, he reasoned that the agreement should assist in "terminating the era of revolutions in this part of South America. [Since] agitation and disorder discredit all of the Latins or Latinized of America. They slow and paralyze the progress of countries which, thanks to the works of peace, can soon be rich and strong, and form a real danger for much of our continent." ${ }^{47}$

44 For a detailed analysis of the Roca-Campos Sales visits, see Ori Preuss, Bridging the Island: Brazilians'Views of Spanish America and Themselves, 1865-1912 (Madrid: Iberoamericana, 2011), pp. 142-158. For historical accounts and analyses of $\mathrm{ABC}$ cooperation, see Delia Otero, "Políticas e ideologías en los procesos de integración del Cono Sur, siglo XX," in Mario Rapoport, and Amado L. Cervo, eds., El Cono Sur: una historia común (México: Fondo de Cultura Económica, 2002), pp. 195-209; Clodoaldo Bueno, Politica externa da primeira república: os anos de apogeu (de 1902 a 1918) (São Paulo: Paz e Terra, 2003), pp. 287-308.

45 Jean Franco, An Introduction to Spanish American Literature, 3rd ed. (Cambridge: Cambridge University Press, 1994), p. 160. For a similar argument, see Miller, In the Shadow of the State, pp. 175-177.

46 José Veríssimo, A educação nacional, 3rd ed. (Porto Alegre: Mercado Aberto, 1985 [1890]), p. 132. Strugforlifista comes from the English motto "struggle for life."

47 A dispatch to the Brazilian legation in Buenos Aires, Nov. 22, 1904, cited in Guilherme Frazão Conduru, "O subsistema americano, Rio Branco e o ABC," Revista Brasileira de Politica Internacional 41:2 (1998), pp. 59-82; my italics. 


\section{Discovering "os ianques do sul"}

If Nabucos' hemispheric project evolved out of a pessimistic view of and identification with Spanish America, then this other sort of Latin Americanismwhich would be equally dominant in Brazilian diplomacy throughout the nineteen-hundreds-evolved out of a simultaneous, optimistic identification. The key here was Brazilians' change of view of their traditional rival, Argentina, the one country which epitomized Spanish America's transition from the times of the caudillos to the times of "order and progress," during the last third of the century. It was the so-perceived metamorphosis of the southern neighbor which fascinated Brazilians, elicited glorifying value judgments, and opened the way for close ties. The War of the Triple Alliance (1865-1870), in which Imperial Brazil joined forces with Argentina's recently established, Eurocentric, liberal regime, to defeat a profoundly caudillistic Paraguay, marked the beginning of this process. Thus for instance, leading Brazilian statesmen, Francisco Otaviano de Almeida Rosa, who went to Buenos Aires in 1865 to establish the alliance, defended it in geopolitical and ethnographic terms alike. Soon after he arrived there, Otaviano's original apprehensions about Argentine expansionism gave way to a resolute defense of the alliance against criticism at home. As revealed in his correspondence, by February 1866 he was convinced that joining forces would help "the two races," the Argentine and the Brazilian, to overcome their mutual hatred and would constitute a basis for reconciliation and friendship. Significantly, this aspiration for a new kind of relationship with the neighbors emerged alongside a fresh perception of their material achievements and character. Buenos Aires, Otaviano reported his discovery back home, was "much more advanced than Rio de Janeiro," and the Argentines themselves were "the Yankees of the South," a dynamic and enterprising people with a great future ahead under its current "civilized" leadership: "this people takes every initiative, attracts every foreigner, destroys every monopoly, and marches forward." 48

The next three decades saw the reinforcement of such images, as the integration of Latin America into the world market led to growing levels of political stability and economic growth, most notably in the River Plate, which, beyond that, also experienced a massive inflow of European immigrants. The emergence of the River Plate not only as "a key nodal point on the world economy" but also as "a focal point in the system of world communication," ${ }^{49}$ meant that information about developments there reached upper class Brazilians in an ever-quickening and increasing stream. New publications arrived at the Brazilian Historical and Geographical Institute and the National Library, as well as falling into the hands

48 Francisco Otaviano to barão de Cotegipe, Montevideo, June 8, 1865, in Wanderley Pinho Cartas de Francisco Otaviano (Rio de Janeiro: Civilização Brasileira, 1977), p. 145.

49 Dwayne Roy Winseck, and Robert M. Pike, Communication and Empire: Media, Markets, and Globalization, 1860-1930 (Durham: Duke University Press, 2007), p. 72. 
of individuals, by way of private and institutional donations or exchanges. Face to face encounters, preceding the one between Nabuco and Darío, took place aboard the growing number of ships connecting Valparaíso, Buenos Aires, and Montevideo with Europe and the United States, which passed through Brazilian ports. These boats also carried the latest editions of Chilean, Argentine, and Uruguayan newspapers that were reproduced occasionally by the Rio press. Likewise, new telegraph lines enabled Brazilian newspapers to report about yesterday's events in the capitals of the above-mentioned countries on a daily basis. Reuters and Havas, the two largest global news agencies, opened joint offices in Recife, Bahia, Rio, Montevideo, and Buenos Aires as early as 1875, thus bringing urban readers along South America's Atlantic coast ever closer not only to Paris, London, and New York, as is often discussed, but also to each other. ${ }^{50}$

Literary critic Susana Zanetti is one of the only scholars to discuss the significance of the proliferation of transnational intellectual crossings inside Latin America during that time. In an important article suggestively titled Modernidad y religación: una perspectiva continental (1880-1916), she has noted that by then ties were no longer limited to just a few writers such as Bello and Sarmiento. "Now, beneath the major figures, whose number had grown significantly (Martí, Darío, Rodó, Silva, Ugarte, etc.), multiple contacts were being created through newspapers and periodicals, through mutual exchange of books, through meetings at congresses, in editorial rooms, in cafés. The letrados were dealing with their singular and national experiences as forming part of a larger dimension." Yet even Zanetti maintains that "this perspective was Hispanic American, since links with Brazil were still scant." 51

As already noted, we maintain that Brazilian letrados did in fact take significant part in the process of religación, not only through the practices mentioned above, but also through visits and sojourns in the River Plate. By the beginning of the twentieth century, dozens of them-from the most well-known political, intellectual, and literary figures of the day, to less-known ones-followed in the footsteps of Otaviano and went South. Motivations and capacities varied from leisure, curiosity and business, to journalism, scientific conferences and diplomacy. Yet the narrated experiences had much in common: a double focus on the material and aesthetic aspects of "progress" - to use the terminology of the time- at the level of physical description, and a sense of amazement, admiration and even infatuation with that "progress" at the level of meaning and emotion.

Eduardo Prado, who visited Buenos Aires in 1882 as part of his grand tour, noted in $A$ ilusão americana that during the 1880s Brazilians had started to look to Porfirio Díaz's Mexico and Argentina as models of economic growth, and that "loutish travelers" who had gone to Argentina's capital became republicans. ${ }^{52}$

50 About telegraph, see ibid., pp. 71-71.

51 Zanetti, p. 492.

52 Prado, $A$ ilusão, p. 64. 
One such traveler, who kept to his monarchist conviction, was Joaquim Nabuco. The celebrated abolitionist visited Argentina three times in 1889, one of them on his honeymoon, and then again in 1891 . These journeys, widely covered by the press in both countries, including travel notes by Nabuco himself, ${ }^{53}$ might have originated in a slightly earlier journey from Rio to the River Plate and back by Portuguese writer Ramalho Ortigão, yet another testimony to the increasing movement along that path. Ortigão's impressions from Argentina were recounted by Nabuco in an extensive article on the front page of Rio's popular daily $O$ Pais in late 1887: "The enthusiasm with which he described what he calls the 'major phenomenon of the Latin race in the nineteenth century,' his endless admiration for a growth unmatched by any other people of our origin, made me embarrassed for having been so many times in Europe and for not having visited yet the River Plate," wrote Nabuco. The picture Ortigão had drawn was "a revelation for me," he concluded, "the Spaniards reproduced something I have never believed they could, the Anglo-Saxon 'miracle' of the United States." ${ }^{4}$ Ortigão's astonishment was recalled in a similar manner a decade later by Rui Barbosa, citing the very same phrase concerning the "Latin race." One cannot imagine how the Argentine capital has grown since then, mused Rui. A quick journey south would reveal to the Brazilian traveler "the marvel of an unexpected world." And this marvel owed to the qualities of a mixed race, "an amalgam of three big Latin families, with some traces of the German and the Anglo-Saxon elements in a very attenuated dose. ${ }^{55}$

Apparently, whether seen with one's own eyes or heard or read about, Argentine reality aroused wonder due to, among other things, the inadequacy of existing concepts. Argentines did not fit neatly into dominant racial, ethno-cultural categories. They seemed to be at the same time Anglo-Saxons and Latins. Or more precisely perhaps, they were a new, Yankeezado kind of Latins. In that they were original. It was an originality submerged in imitation, but an originality all the same, embodying the promise of a distinctively Southern type of progress, of a Latin America in the making that was leaving behind its caudillistic, barbarous past.

\section{Epilogue}

In October 1908 Rui Barbosa delivered an extensive speech before the Brazilian Senate, published later that year as a pamphlet titled $O$ Brasil e as naçôes latino-americanas em Haya. Given in direct response to allegations by former Argentine minister of foreign relations Estanislao Zeballos concerning Brazil's conduct at the 1907 Hague International Peace Conference under Rui's leadership, it encapsulates the main themes and arguments of this article. The first of which is

53 Joaquim Nabuco, “De Buenos Aires,” O Paiz, Aug. 12, 13, 15, 19, 1891.

54 O Paiz, Dec. 4, 1887.

55 Rui Barbosa, “Nacionais e estrangeiros,” A Imprensa, Oct. 19, 1898. 
the volume and rapidity of the transnational exchange of ideas between Brazilian and Spanish American intellectuals in the late nineteenth and early twentieth century. It is telling that Zeballos's accusations were reported in detail only a day before the speech in the "Telegrams" section of Rio's Jornal do Comércio-yet another sign of the communicational integration of the two countries. It is also telling that in replying to the accusation that the Brazilian delegates had been unsympathetic to their Argentine counterparts, Rui recounted in detail the friendly personal contacts he had established with Luis María Drago, Carlos Rodríguez Larreta, and Roque Sáenz Peña. He got to know the first, author of the famous Drago Doctrine (1902) against the use of force for the collection of public debts from Latin American countries, already onboard the ship that carried both men to Europe: one out of numerous Luso-Hispanic maritime encounters of the same nature. After the conference, back in Buenos Aires, Drago would send Rui a copy of his recently published translation of Thomas Carlyle's Doctor Francia, a text whose original version served as the basis of Rui's previously mentioned Duas glórias da humanidade. Future President of Argentina, Sáenz Peña, on his part, presented the Brazilian jurist his own Derecho público americano (1905). ${ }^{56}$ These two works, whose themes reflect the shared macro-regional cultural horizon of Brazilian and Spanish American statesmen-writers, thus joined dozens of Spanishlanguage titles in Rui's personal library and in other private and public collections in Rio de Janeiro.

In that thickening web of transnational intellectual exchange, regional projects and policies — and this is the second point to be made-, Argentina played a pivotal role, both conceptually and practically. For Brazilians it stood for an emerging Latin America, vigorous and virile, as is apparent in Rui's allusion to the three Argentine delegates as the incarnation of "the qualities and virtues of their race, its brilliance, robustness, notable force of expansion, assimilation and progress." 57 To be sure, this admiring vision of the southern neighbor's forceful and dynamic Latinity did not mean the disappearance of old national hatreds and intense bilateral rivalry. Late nineteenth century Argentina represented both a threat and a promise and Brazil's foreign policy toward it oscillated, accordingly, between fierce competition for power and prestige on the one hand, and closer ties and growing cooperation on the other. Thus, during The Hague, Brazil's conduct shifted from a pro-US stand to championship of the rights of smaller nations, and those of Latin America in particular, in face of the interests of the United States and the European powers. Rui Barbosa, who in the beginning of the conference used his famous oratorical talent to attack the Drago Doctrine, had become, eventually, the major voice for the Latin American countries, sketching, in his closing speech,

56 Rui Barbosa, O Brasil e as naçôes latino-americanas em Haya (Rio de Janeiro: Imprensa Nacional, 1908), pp. 19-21,

57 Ibid, p. 19. 
"the great currents of progress which now rapidly transform them, the immanence of their future greatness." 58

Much like other texts and policies mentioned in this article, Rui's diplomatic mission at The Hague itself and his speech at the Brazilian Senate have rarely, if ever, been considered as expressions of Latin Americanism. It is our contention that they were. Here was a clear, highly publicized political use of the concept of "Latin America" in the sphere of international relations by an eminent intellectual acting on behalf of his state. This version of Latin Americanism differed from the dominant Arielista sort both in terms of contents and the social identity of its authors. It emanated from within the Brazilian oligarchic regime, rather than produced by new independent "modern intellectuals," and, accordingly, it was less literary, abstract and continentalist, and more mundane, concrete, and nationalist, intimately entwined with foreign politics. And while it shared with Arielismo the basic notion of "Latin America" as a discrete entity, a certain vindication of this entity, and a preoccupation with US imperialism, it did not enforce but rather blurred the Ariel/Caliban, spiritualism/utilitarianism dichotomy, as epitomized in the expressions "the Yankees of the south," and "The United States of South America." The main dichotomies at work here were those of order/disorder, backwardness/progress, weak/strong, dichotomies produced and reproduced together with a dual view of Latin America that was at once racialist-essentialist and cultural-historical. In this view, Argentina, Chile, and Brazil, as well as Mexico, belonged in the category of order, progress, and virility, though even they were rarely seen as fully liberated from the negative racial traits and historical experiences of the "Latin" peoples of America. In the same way that the so-perceived disordered and vulnerable republics were not always excluded from an all-encompassing vision of Latin American order and progress.

Both pessimist and optimist conceptualizations of "Latin America" nurtured the realist, statist variants of Latin Americanism, which in practice were not necessarily disjoined from the idealist ones, yet have received much less scholarly attention. Filling this lacuna, however, is beyond the scope of this article, whose main purpose has been double. First, to demonstrate some of the largely overlooked participation of Brazilians in debates about "Latin America" around 1898. And second, to highlight the entangled Luso-Hispanic nature of this participation. Evidently, transnational gazes, dialogues, encounters and sojourns across the River Plate and the Amazon contributed significantly to the formation of Latin American identities. And it would therefore be wrong to let the Yankees' role overshadow the important role of the ianques do sul.

Submitted in October 2, 2013 Approved in October 31, 2013

58 Ibid, p. 15; Smith, Unequal Giants, pp. 59-62. 


\section{Abstract}

The article reconstructs the largely forgotten role of key Brazilian intellectuals in the Latinsversus-Anglo-Saxons debates that developed around 1898, emphasizing the embeddedness of their thinking in the transnational crossings of men and ideas within South America. It thus challenges the common depiction of late-nineteenth-century Latin Americanism as a purely Spanish American phenomenon and of the United States as its major catalyst, allowing a more nuanced understanding of this movement's nature.

Keywords: Brazil; entangled history; intellectual exchange; Latin America; transnationalism.

\section{Resumo}

O artigo reconstrói o papel esquecido de intelectuais brasileiros nos debates latinos-contraanglo-saxões que se desenvolveram em torno de 1898, enfatizando o enraizamento de seus pensamentos nos cruzamentos transnacionais de homens e ideias na América do Sul. Assim, desafia a representação comum do latino-americanismo do fim do século 19 como um fenômeno puramente hispano-americano e dos Estados Unidos como seu principal catalisador, permitindo uma compreensão mais sutil deste movimento.

Palavras-chave: Brasil; história entrelaçada; intercâmbio intelectual; América Latina; transnacionalismo. 